\title{
Vitamin C and Total Sugar Content Characterization on 31 Accessions of Banana Collection of Banana Germplasm Plants of Yogyakarta
}

\author{
Siti Dewi Indrasari ${ }^{1}$, Kristamtini ${ }^{2}$, Endang Wisnu Wiranti ${ }^{3}$ \\ ${ }^{1,2,3}$ Assessment Institute for Agricultural Technology (AIAT) Yogyakarta \\ Jln. Stadion Maguwoharjo No. 22, Wedomartani, Ngemplak, Sleman, Yogyakarta, Indonesia \\ Author correspondency: \\ dewindrasari@yahoo.com ${ }^{1}$
}

\begin{abstract}
Banana is one of the tropical fruits that people like because it tastes good and contains good nutritional value that beneficial for health. The content of vitamin $\mathrm{C}$ and total sugar are an important character to complete the morphological characterization of banana accession that can be utilized by breeders in choosing accession as parent. The study aimed to determine the content of vitamin $\mathrm{C}$ and total sugar on 31 accessions of banana collection of Banana Germplasm Plants of Yogyakarta. The research was conducted at Banana Germplasm Plantation and Laboratory of Agricultural Technology Production of Gadjah Mada University, Yogyakarta from January to December 2016. The results indicated that 31 banana accessions showed their susceptibility to vitamin $C$ content $60.42 \pm 39.22 \mathrm{mg} / 100 \mathrm{~g}$ and total sugar $22.06 \pm 16.01 \%$. High standard deviation values indicate the large diversity of banana accessions that were characterized, indicating that the accessions of each characterized banana were separate accessions of one another.
\end{abstract}

Keywords: Characterization; banana; vitamin C; total sugar.

\section{INTRODUCTION}

Banana is one of the tropical fruits that people like because it tastes good and contains good nutritional value that beneficial for health. In addition to the relatively cheap price, banana was also one of the plants that have bright prospects because everyone in the whole world almost likes to consume bananas (Komaryati \& Adi, 2012).

Indonesia is one of the centers of banana plant genes (Sukartini, 2007). Therefore, in 1988, the Goverment of Yogyakarta Special Region develop the Banana Germplasm Garden and has been carry out the collection, maintenance and dissemination of various collections of bananas. With a land area of 19,525 square meters, this garden already has 346 varieties of bananas originating from Indonesia and from abroad (Kristamtini et al., 2016). The Banana Germplasm Garden of Yogyakarta was called as the most complete collection of banana conservation garden in Indonesia by the Ministry of Agriculture of Indonesia.

Indonesia has a high diversity of bananas, this condition was very helpful for breeding program in producing superior varieties. The superior varieties of bananas were expected to have high productivity, good quality, early age, resistant to certain pests and tolerance to environmental stress. On the other hand, in the banana diversity was not yet widely known for its characteristics. To support the assembly of superior varieties of bananas, it was necessary to characterize and evaluate existing germplasm. The information obtained from characterization and evaluation, can be used as a material for improving the character through a plant breeding program.

Banana plants have diverse morphological characters. Each banana plant has its advantages and disadvantages based on its morphological appearance (Wardiyati et al., 2004). As the first step of breeding program to get information about morphological character of a plant was needed characterization activity (Subandiyah, 2002). As Simmonds \& Shepherd (1955) have pointed out, one of the first steps to recognize the magnitude of such biodiversity was to identify genetic diversity. One approach to identifying a banana plant is to use morphological characters that include leaf, stem, fruit, and flower characters (Wardiyati et al., 1997) Plant breeders can utilize the plant after knowing the character thoroughly through exploration, collection, characterization, evaluation and selection (Wardiyati et al., 1997).

Morphological characterization is the preliminary information required in seeking superior characters and the diversity that was still in need (Santos et. al., 2003). Morphological characters were considered still not enough to find a clear position so that other methods as complement to evaluate kinship. One method was to do chemical characterization by analyzing the content of vitamin $\mathrm{C}$ and total sugar. The content of vitamin $\mathrm{C}$ and 
total sugar becomes the character that differentiates between accessions, because bananas contain high enough nutrients and high of vitamin $\mathrm{C}$. In addition the content of Vitamin $\mathrm{C}$ and total sugar was the required character in the description of banana plants

The aim of this research was to know and get the diversity of 31 accessions of banana collection of Banana Germplasm Garden of Yogyakarta based on vitamin $\mathrm{C}$ and total sugar content so that the relation of various bananas based on vitamin $\mathrm{C}$ and total sugar content are known.

\section{MATERIALS AND METHODS}

The experiment was conducted at Banana Germplasm Plantation and Agricultural Production Technology Laboratory of Gadjah Mada University, Yogyakarta from January to December 2016. Thirty-one accessions of banana as research material are presented in Table 1. Banana tree ripe fruit was analyzed for vitamin $\mathrm{C}$ and total sugar content. The analysis of sugar content using Nelson Somogyi method, while analysis of vitamin C content using iodometric titration method.

Table 1. The banana accessions and its origin.

\begin{tabular}{|c|c|c|}
\hline No & Name & Origin \\
\hline 1 & Ambon Jaran & Bantul \\
\hline 2 & Ambon Sepet & Gunung Kidul \\
\hline 3 & Ambon Warangan & Kulon Progo \\
\hline 4 & Anjasmoro & Sleman \\
\hline 5 & Australi & KBH Dongkelan \\
\hline 6 & Gajih Putih & Kulon Progo \\
\hline 7 & Kepok Brentel & Bantul \\
\hline 8 & Kepok Bung & Kulon Progo \\
\hline 9 & Kepok Hijau & Sleman \\
\hline 10 & Kepok Kuning & KBH Dongkelan \\
\hline 11 & Kidang Hijau & Sleman \\
\hline 12 & Kluthuk Susu & Yogyakarta \\
\hline 13 & Koja Pretel & Gunung Kidul \\
\hline 14 & Koja Sirimentak & Gunung Kidul \\
\hline 15 & Lempereng & Kulon Progo \\
\hline 16 & Mangsan & Sleman \\
\hline 17 & Mas Raja & Sleman \\
\hline 18 & Mas Sloka & Kulon Progo \\
\hline 19 & Mas Tropong & Sleman \\
\hline 20 & Morosebo & Yogyakarta \\
\hline 21 & Potho Merah & Bantul \\
\hline 22 & Raja Bagus & Yogyakarta \\
\hline 23 & Raja Bandung & Bantul \\
\hline 24 & Raja Lini & Gunung Kidul \\
\hline 25 & Raja Pulut & Yogyakarta \\
\hline 26 & Raja Sabrang & Kulon Progo \\
\hline 27 & Raja Sawi & Sleman \\
\hline 28 & Raja Sewu & Yogyakarta \\
\hline 29 & Rejang & Sleman \\
\hline 30 & Serawak & Kulon Progo \\
\hline 31 & Triolin & Bantul \\
\hline
\end{tabular}

The data of vitamin $\mathrm{C}$ content and total sugar were analyzed by cluster method using hierarchical cluster analysis to know the kinship relationship with the help of SAS ver software 9.2. Hierarchical cluster analysis was a common way to grouping objects in groups that share the same resemblance to each other.

\section{RESULTS AND DISCUSSION}

The content of vitamin $\mathrm{C}$ and total sugar in 31 accessions of bananas is presented in Table 2. The content of vitamin $\mathrm{C}$ and total sugar from 31 banana accessions varies according to their genetic potential, with an average vitamin $C$ content of $60.42 \pm 39.22$ $\mathrm{mg} / 100 \mathrm{~g}$, average of total sugar $22.06 \pm 16.01 \%$. The highest vitamin $\mathrm{C}$ content is owned by the Mangsan accessions (149.34 mg/100g) and the lowest is owned by the Mas Raja accessions $(12.79 \mathrm{mg} / 100 \mathrm{~g})$. The content of vitamin $\mathrm{C}$ in 31 accessions of bananas is a hint of accession of bananas to be selected for consumption as fresh fruit that is beneficial to health.

Table 2. The content of vitamin $\mathrm{C}$ and total sugar of 31 bananas accessions.

\begin{tabular}{lcc}
\hline Bananas Accessions & Vit C $(\mathbf{m g} / \mathbf{1 0 0} \mathbf{g})$ & Total Sugar $(\boldsymbol{\%})$ \\
\hline \hline 1. Ambon Jaran & 20.41 & 20.41 \\
2. Ambon Sepet & 128.20 & 18.54 \\
3. Ambon Warangan & 52.44 & 15.19 \\
4. Anjasmoro & 34.38 & 17.01 \\
5. Australi & 53.14 & 2.42 \\
6. Ceni & 36.50 & 21.70 \\
7. Gajih Putih & 76.14 & 10.66 \\
8. Kapok Brentel & 30.85 & 20.31 \\
9. Kepok Bung & 135.69 & 17.25 \\
10. Kepok Hijau & 23.34 & 23.34 \\
11. Kepok Kuning & 93.48 & 18.99 \\
12. Kidang Hijau & 82.93 & 17.90 \\
13. Klutuk Susu & 61.70 & 21.36 \\
14. Koja Pretel & 27.39 & 22.73 \\
15. Koja Sirimentak & 50.38 & 13.20 \\
16. Lempereng & 20.52 & 20.07 \\
17. Mangsan & 149.34 & 14.36 \\
18. Mas Jambe & 75.53 & 16.38 \\
19. Mas Raja & 12.79 & 44.85 \\
20. Mas Sloka & 92.15 & 18.99 \\
21. Mas Tropong & 98.84 & 16.96 \\
22. Morosebo & 85.78 & 14.31 \\
23. Potho Merah & 19.40 & 19.40 \\
24. Raja Bandung & 57.93 & 15.66 \\
25. Raja Lini & 17.79 & 22.97 \\
26. Raja Pulut & 122.29 & 20.94 \\
27. Raja Sabrang & 54.43 & 15.64 \\
28. Raja Sewu & 31.08 & 22.31 \\
29. Rejang & 104.37 & 10.88 \\
30. Serawak & 17.38 & \\
31. Triolin & 12.62 & \\
Average + SD & $92 \pm 39.22$ & \\
Min - Max & & \\
\hline
\end{tabular}


Vitamin $\mathrm{C}$ or ascorbic acid is needed for health. In human body vitamin $\mathrm{C}$ serves as an antioxidant that can protect the body, especially cellular DNA from damage due to oxidation of free radicals. Antioxidants prevent oxidative stress and play an important role in the development of chronic and degenerative diseases such as cancer, arthritis, autoimmune disease, cardiovascular and neurodegenerative diseases (Lian et al., 2008 in Harifah et al., 2017). Daily requirement for vitamin C vary for each individual, in general experts estimate that $60 \mathrm{mg}$ per day is enough but in certain conditions the body requires more than that (Sitohang, 2006). Based on Widya Karya Nasional Pangan dan Gizi V (1993), the requirement of vitamin $\mathrm{C}$ per day for baby (7-12 months) is $35 \mathrm{mg}$, childrem (7-9 year) is $45 \mathrm{mg}$ and women and men ( 20 - 59 year) is $60 \mathrm{mg}$.

It appears in Table 2 that accessions of bananas that have a high vitamin $\mathrm{C}$ content followed by a low total sugar content. This means that there is a negative correlation between vitamin $\mathrm{C}$ content and total sugar on 31 accessions of bananas observed. Correlation analysis result showed negative correlation equal to - 0.41.

Furthermore, from the chemical characteristic data of vitamin $\mathrm{C}$ content and total sugar was used for cluster analysis with the result of dendogram in Figure 1.

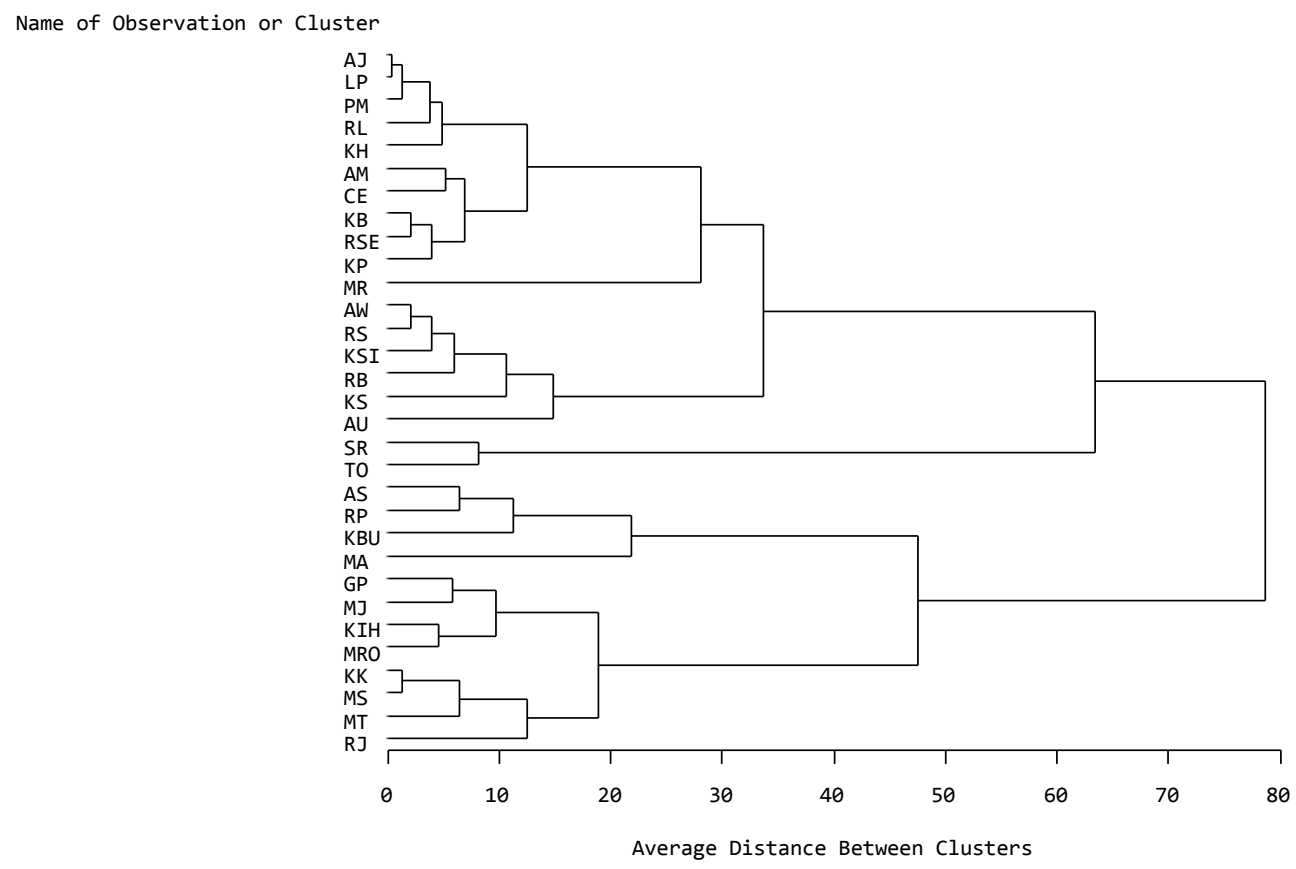

Information:

1. Ambon Jaran

2. Ambon Sepet

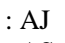

: AJ

12. Kidang Hijau

: KIH

22. Morosebo

: MRO

3. Ambon Warangan : AW

4. Anjasmoro : AM

5. Australi

13. Klutuk Sus

: KS

3. Potho Merah

PM

15. Koja Sirimentak

24. Raja Bandung

: RB

: AM

16. Lempereng

5. Raja Lini

RL

6. Ceni

7. Gajih Putih

8. Kapok Brentel

17. Mangsan

6. Raja Pulut

RP

: GP 18. Mas Jambe

: LP

: MA

19. Mas Raja

20. Mas Sloka

27. Raja Sabrang

RS

: KB

10. Kepok Hijau

: KH 21. Mas Tropong : MT

8. Raja Sewu

RSE

:MR

:MS

29. Rejang

30. Serawak

31. Triolin

: RJ

11. Kepok Kuning

: KK

Figure 1. Dendogram of 31 banana accession of Banana Germplasm Garden collection of based on vitamin C and total sugar content.

Dendogram of Figure 1 shows the kinship relations of 31 banana accessions based on vitamin $\mathrm{C}$ and total sugar content. There appears to be some accessions that have very close kinship i.e. accession AJ (Ambon Jaran) with accession LP (Lempereng); and accession KK (Kepok Kuning) with MS accession (Mas Sloka). But among these accessions there is no equal accession to other accessions, meaning there is no duplication of names between the accessions. And each accession is a separate accession with one accession to another. This result is supported by the morphological character of the fruit, presented in Figure 2. 
Dendogram of Figure 1 shows that 31 banana accessions based on vitamin $\mathrm{C}$ content and total sugar were divided into 5 groups. Group I consists of 11 accessions of bananas ie: AJ (Ambon jaran); LP (Lempereng); PM (Potho Merah); RL (Raja Lini); KH (Kepok Hijau); AM (Anjasmoro); CE (Ceni); KB (Kepok Brentel); RSE (Raja Sewu); KP (Kojo Pretel) and accession of MR (Mas Raja). Group II consists of 7 accessions of bananas ie: AW (Ambon Warangan); RS (Raja Sabrang); KSI (Kojo Sirimentak); RB (Raja
Bandung); KS (Kluthuk susu); AU (Australi);. Group III consists of 2 accessions of bananas ie: SR (Serawak); and TO (Triolin). Group IV consists of 4 accessions of bananas ie: AS (Ambon Sepet); RP (Raja Pulut); KBU (Kepok Bung); And MA (Mangsan); and Group V consists of 8 accessions of bananas ie: GP (Gajih Putih); MJ (Mas Jambe); KIH (Kidang Hijau); MRO (Morosebo); KK (Kepok Kuning); MS (Mas Sloka); MT (Mas Tropong); And RJ (Rejang).

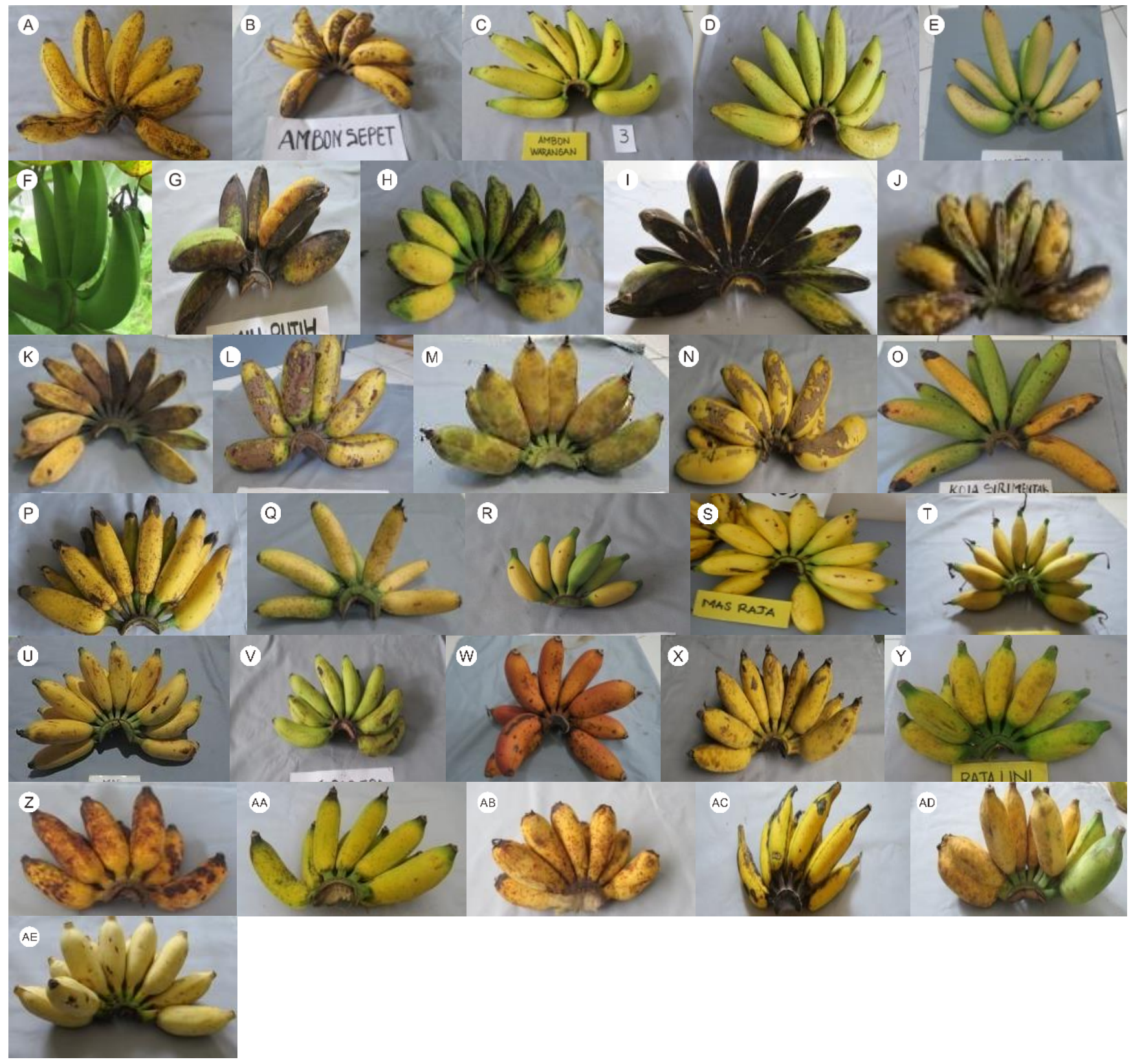

Figure 2. Bananas fruit of 31 bananas accessions. (A). Ambon Jaran; (B). Ambon Sepet; (C). Ambon Warangan; (D). Anjasmoro; (E). Australi; (F). Ceni; (G). Gajah Putih; (H). Kepok Brentel; (I). Kepok Bung; (J). Kepok Hijau; (K). Kepok Kuning; (L). Kidang Hijau; (M). Kluthuk Susu; (N). Koja Pretel; (O). Koja Sirimentak; (P). Lempereng; (Q). Mangsan; (R). Mas Jambe; (S). Mas Raja; (T). Mas Sloka; (U). Mas Tropong; (V). Morosebo; (W). Potho Merah; (X). Raja Bandung; (Y). Raja Lini; (Z). Raja Pulut; (AA). Raja Sabrang; (AB). Raja Sewu; (AC). Rejang; (AD). Serawak; (AE). Triolin. 


\section{CONCLUSION}

From the result we draw conclusion as follows:

1. The content of vitamin $\mathrm{C}$ and total sugar from 31 accessions of bananas vary according to their genetic potential, with an average vitamin $\mathrm{C}$ content of 60.42 $\pm 39.22 \mathrm{mg} / 100 \mathrm{~g}$ and average total sugar $22.06 \pm$ $16.01 \%$.

2. Each banana accession from 31 accession was a separate accession one with another accession and is divided into 5 groups based on vitamin $\mathrm{C}$ content and total sugar.

\section{REFERENCES}

Anonim. 1993. Daftar Angka Kecukupan Gizi yang Dianjurkan. Widya Karya Nasional Pangan Gizi ke V. Jakarta

Komaryati \& Adi, S. 2012. Analisis faktor-faktor yang mempengaruhi tingkat adopsi teknologi budidaya pisang kepok (Musa paradisiaca) di Desa Sungai Kunyit Laut. Kecamatan Sungai. Kabupaten Pontianak. J. Tiprekas: 53-61.

Kristamtini, Wiranti, EW., Indrasari, SD., Wirasti, Ch.A., \& Sutarno. 2016. Deskripsi Aksesi Pisang Koleksi Kebun Plasma Nutfah Pisang Yogyakarta Tahun 2016. BPTP Yogyakarta.

Harifah, I., Mustofa, A., Suhartatik, N., 2017. Aktivitas antioksidan infuse water dengan variasi jenis jeruk (nipis, lemon, dan baby) dan buah tambahan (strawberry, anggur hitam, dan kiwi). ejurnal.unisri.ac.id/index.php/jtpr/article/download/1517/1335 . Retrieved at 23 August 2017.

Santos, E.A., Souza, M.M., Viana, A.P., Almeida, AAF., Freitas, JCO., \& Lawinsky, PR.. 2011. Multivariate analysis of morphological charateristics of two species of passion flower with ornamental potential and of hybrids between them. Gen. Mol. Res. 10 (4): 2457-2471.

Simmonds, N.W. and Shepherd, K. 1955. The taxonomy and origins of the cultivated bananas. Lennean Soc Bot. 55: 302312.

Sitohang, A. Pengaruh konsentrasi gula dan suhu pengering terhadap mutu pada pembuatan sirup markisa. Media Unika Tahun 26 No. 87. Edisi 1.

Subandiyah. S, Sumardiyono, Christanti, Rumahlewang \& Wilhelmina, W. 2002. Pengimbasan ketahanan pisang terhadap penyakit Layu Bakteri (Ralstonia solana cearum) dengan Pseudomonas cepacia Jurnal Agrosains 15 (1): 9-16.

Sukartini. 2007. Pengelompokan Aksesi Pisang Menggunakan Karakter Morfologi IPGRI. J. Hort 17 (1).

Wardiyati. T, Retnowati. A, \& Widaryanto, E. 1997. Ketahanan Empat Kultivar Pisang Terhadap Kekeringan. Jurnal Agrivita 20 (3): 167-170.

Wardiyati. T, Sugianto. A, Nugroho. A, Lamadji. S, \& Mugiono. 2004. Perbaikan Sifat Pisang Kepok melalui Mutasi Buatan Sinar Gamma; Keragaman Fase Genetik. Jurnal Ilmu Hayati 16 (2): $90-98$. 
THIS PAGE INTENTIONALLY LEFT BLANK 